\title{
Amadis de Gaule. Livre I (traduction Herberay des Essarts), édition critique par Michel Bideaux
}

\section{Michele Mastroianni}

\section{(2) OpenEdition}

1 Journals

\section{Edizione digitale}

URL: http://journals.openedition.org/studifrancesi/9152

DOI: 10.4000/studifrancesi.9152

ISSN: 2421-5856

\section{Editore}

Rosenberg \& Sellier

\section{Edizione cartacea}

Data di pubblicazione: 1 juin 2008

Paginazione: 172-173

ISSN: 0039-2944

\section{Notizia bibliografica digitale}

Michele Mastroianni, «Amadis de Gaule. Livre I (traduction Herberay des Essarts), édition critique par Michel BideauX», Studi Francesi [Online], 154 (LII | I) | 2008, online dal 30 novembre 2015, consultato il 13 janvier 2021. URL: http://journals.openedition.org/studifrancesi/9152 ; DOI: https://doi.org/ 10.4000/studifrancesi.9152

Questo documento è stato generato automaticamente il 13 janvier 2021.

\section{(c)}

Studi Francesi è distribuita con Licenza Creative Commons Attribuzione - Non commerciale - Non opere derivate 4.0 Internazionale. 
Amadis de Gaule. Livre I (traduction Herberay des Essarts), édition critique par Michel Bideaux

Michele Mastroianni 


\section{NOTIZIA}

Amadis de Gaule. Livre I (traduction Herberay des Essarts), édition critique par Michel BIDEAUX, Paris, Champion, 2006 («Textes de la Renaissance», 116), pp. 707.

Dopo la pubblicazione, in edizione critica a cura di Luce Guillerm, del quarto libro (cfr. questi «Studi», 150, 2006, p. 589) della traduzione/adattamento che Herberay des Essarts ha fatto dell'Amadís de Gaula di Garcí Rodriguez de Montalvo, esce ora a cura di Michel Bideaux l'edizione critica del primo libro. Trattandosi del volume con cui si apre l'intera opera (ricordiamo che è in progetto la pubblicazione dei ventiquattro libri dell'Amadis, sia quelli procedenti da un originale spagnolo sia quelli derivati dall'italiano e dal tedesco), abbiamo un discorso introduttivo che illustra il significato culturale dell'Amadís de Gaula spagnolo (a cura di Victoria Cirlot, pp. 10-41), disegna la diffusione europea degli 'Amadigi' e inquadra la personalità di Herberay des Essarts come traduttore-scrittore, per ricostruire infine la fortuna e la ricezione critica degli Amadis in Francia. Nell'introduzione relativa al primo libro (pp. 85-157), vengono dibattuti i problemi critici che pongono le varie edizioni cinquecentesche dell'adattamento di Herberay, e vengono poi, attraverso anche un riassunto ragionato, analizzati gli elementi costitutivi del libro, che assume caratteri nettamente umanistici a livello strutturale, nella ricostruzione degli ambienti - la corte in particolare - e nella distribuzione attanziale. Lavoro esemplare per rigore filologico, la presente edizione offre un'annotazione linguistica puntuale e un'analisi minuziosa degli interventi del traduttore. Preciso il glossario. Il volume termina con accurati indici: dei personaggi, dei toponimi, delle tematiche. 